\title{
Performance of 'Valencia' Sweet Orange Trees on 12 Rootstocks at Two Locations and an Economic Interpretation as a Basis for Rootstock Selection
}

William S. Castle ${ }^{1}$, James C. Baldwin, and Ronald P. Muraro

University of Florida, IFAS, Horticultural Sciences Department, Citrus Research and Education Center, 700 Experiment Station Road, Lake Alfred, FL 33850

\section{Ramon Littell University of Florida, IFAS, Statistics Department, Gainesville, FL 32611}

Additional index words. Carrizo citrange, Citrus sinensis, discounted cash flow, internal rate of return, sweet orange cuttings, Swingle citrumelo, Volkamer lemon

\begin{abstract}
Two field experiments with 'Valencia' sweet orange [Citrus sinensis (L.) Osb.] trees propagated on 12 rootstocks were conducted in commercial orchards. The objectives were to compare rootstock horticultural performance between two locations with soils representative of the Central Florida Ridge (AP) and coastal flatwoods (I), the major citrus-growing regions in Florida, and to see if financial analysis would provide an improved basis for interpreting rootstock performance. The randomized complete-block trials involved six-tree plots replicated eight or 10 times at planting densities of 358 trees (AP) or 252 trees (I)/ha, respectively. Tree growth and survival, yield, and juice quality were measured for 15 years. When losses occurred, trees were replaced annually with another one on the same rootstock. The data of seven rootstocks were subjected to a financial interpretation of three scenarios: tree loss and tree loss with or without tree replacement using the discounted cash flow and internal rate of return methods at a $15 \%$ rate. At the flatwoods location, when differences among replications became apparent on several rootstocks, soil data were collected to study its possible association to tree performance; also in this trial, $400-\mathrm{kg}$ fruit samples were differentially harvested in 2 successive years from mature trees on each of five commercial rootstocks when the juice soluble solids/acid ratio was near 15 . The juice was extracted, pasteurized, and evaluated for flavor by an experienced taste panel. The horticultural data obtained for trees on specific well-studied rootstocks [Volkamer (C. volkameriana Ten. \& Pasq.)] and rough (C. jambhiri Lush.) lemons, Carrizo citrange $[C$. sinensis $\times$ Poncirus trifoliata $(\mathrm{L})$.$] , sour$ orange $[C$. aurantium (L.)], Cleopatra mandarin (C. reshni Hort. ex Tan.), trifoliate orange ( $P$. trifoliata), a selection of sweet orange $(C$. sinensis), and Swingle citrumelo $(C$. paradisi Macf. $\times P$. trifoliata) at both locations were typical of their well-documented performance in Florida and elsewhere. Tree losses were virtually only from citrus blight and ranged from none (sour orange) to greater than $\mathbf{5 0 \%}$ (Volkamer and rough lemons) at both locations, although tree loss began later at the Central Florida location. 'Valencia' cuttings (only at the flatwoods site) were long-lived and cropped well for their smaller size compared with the budded trees. Taste panelists were not able to distinguish differences over two seasons among pasteurized 'Valencia' juices produced from trees on different rootstocks and normalized by soluble solids/acid ratio. Yield and planting density were the main factors affecting financial outcome; also, in the highly variable soils of the coastal flatwoods, trees growing in sites with greater depth to an argillic layer had $30 \%$ to $\mathbf{2 0 0} \%$ higher yields. Trees on Volkamer lemon had only $\approx \mathbf{5 0 \%}$ survival at both locations but had the highest $(\$ 7,338 / \mathrm{ha} I)$ or one of the highest cash flows $(\$ 13,464 /$ ha AP) as compared with one of the commercial standards, Carrizo citrange (\$6,928 I; $\$ 16,826 \mathrm{AP})$, which had only $\approx 25 \%$ tree loss. Inclusion of financial analysis, with certain limitations, was concluded to considerably improve rootstock selection decisions compared with selection based only on horticultural data.
\end{abstract}

Most tree fruit industries succeed on the availability of suitable high-quality scions and rootstocks and profitable combinations as dictated by a wide range of factors (Castle and Gmitter, 1998). Choosing a citrus rootstock is commonly determined by compati- bility with the scion; its tolerance to various pests, diseases, soil, and site, and other environmental conditions; and the influence of the rootstock on yield and fruit quality (Castle, 1987, 1995; Wutscher, 1979). Sometimes a rootstock is developed or evaluated for a specific purpose, e.g., tree size control, tolerance to certain specific circumstances like high $\mathrm{pH}$ or calcareous soils, sites prone to flooding, nematodes, or virus or viroid diseases (Bauer et al., 2005; Castle and Baldwin, 2005; Castle and Phillips, 1977, 1980; Castle et al., 2004, 2009; Phillips and Castle, 1977).

Choosing a citrus rootstock is a deliberate action aimed at specific objectives and designed to ensure tree survival, long-term performance, and profit. The foundation of those decisions has been identifying and characterizing rootstock traits in screening trials, formal field trials in which significant variability can occur between and within sites (Bevington and Cullis, 1990; Castle, 1983; Castle and Baldwin, 1995; Castle et al., 2000; Economides, 1993; Foguet, 2000; Hutchison et al., 1992; Roose et al., 1989; Stover and Castle, 2002; Wheaton et al., 1991, 1995a, 1995b; Wutscher and Bistline, 1988; Wutscher and Bowman, 1999; Wutscher and Hill, 1995), commercial experience, and more recently, the use of molecular marker techniques to assess germplasm in advance of field trials (Gmitter et al., 2007; Ling et al., 2000). Typically, the information gathered from those combined sources is assembled into summary charts that are used as a guide for rootstock selection (Castle et al., 1993, 2006; Ferguson et al., 1990; Newcomb, 1978). It is uncommon that additional or better selection criteria have been developed for making citrus rootstock decisions. The generalities of the charts are usually compiled from years of research and commercial evaluation. They represent both the inherent weaknesses and strengths associated with selection guides: weakness in that the rootstock characterizations are often derived from local or regional experiences and may be based on limited information; and strength in that the traits given in a chart are usually accurate and, thus, reliable in guiding the selection process. However, the charts do not directly provide any information about profitability or risk.

Using a rootstock selection chart has risks. Individual traits listed in a selection chart may not have equal importance in the selection process. The Florida citrus industry, for example, is largely composed of orange groves with fruit grown for juice products. Growers are compensated for juice soluble solids content. Fresh fruit citrus growers, like with other tree crops, earn their income by selling a high-quality product defined by such factors as fruit size, internal quality, and external color. The choice of citrus rootstocks in those two instances may be different.

An alternative approach is to complement horticultural performance data with economic analysis as has been applied in apple (Robinson and Hoying, 2004; Robinson et al., 1991, 2007) and citrus (Boswell et al., 1975, 1978) planting systems research to determine profitability. The commercial apple industry has steadily moved to increased planting density supported by research results. Those studies have shown that high yields can be obtained over a range of planting systems and densities, but when 
the horticultural outcomes were subjected to a financial interpretation, there were optimum densities. Those studies were also useful in demonstrating how profitability responded to changes in fruit prices, the cost of nursery trees, and yield. One of the earliest reports in Florida about "Economic Aspects of Citrus Stocks and Scions" (Ziegler, 1966) took up the issue of risk in association with matching scions and rootstocks based primarily on the body of knowledge available, i.e., the greater the knowledge, the lower the risk. The favorable financial consequences of matching scion-rootstock combinations and planting density were demonstrated later in Florida field trials (Muraro et al., 1995; Wheaton et al., 1995a) and California (Boswell, et al., 1975, 1978). Nevertheless, financial interpretations are not a routine part of citrus scion and rootstock breeding and evaluation programs (Bevington and Cullis, 1990; Breedt et al., 1996; Foguet, 2000; Rouse, 2000).

Our objectives were to: 1) conduct a longterm field test of citrus rootstocks to gather routine horticultural data and observe responses to citrus blight; and 2) determine if adding financial interpretations would result in an improved means for selecting a rootstock, one that would be robust enough to be useful across a range of experimental conditions. Furthermore, we hypothesized that yield would be the primary factor determining profitability in an orange grove of fruit grown for processing and would be of sufficient significance to override other normally important factors such as site conditions, disease tolerance, and fruit juice quality.

\section{Materials and Methods}

Plant materials. Rootstock seedlings grown from Florida seed sources were propagated with a commercial 'Valencia' nucellar clone (V-S-SPB-1-21-30XE) in the field nursery of the Citrus Budwood Registration Bureau, Florida Division of Plant Industry, Winter Haven.

Trial locations. The trees were planted in commercial groves located near Avon Park (lat. $27^{\circ} 34^{\prime} 02^{\prime \prime} \mathrm{N}$; long. $81^{\circ} 28^{\prime} 08^{\prime \prime} \mathrm{W}$ ) and Indiantown (lat. $27^{\circ} 00^{\prime} 53^{\prime \prime} \mathrm{N}$; long. 80 $83^{\prime} 56^{\prime \prime} \mathrm{W}$ ) in Feb. 1977 and Nov. 1976, respectively. The Avon Park grove typifies the Central Florida

Received for publication 28 Sept. 2009. Accepted for publication 18 Feb. 2010.

The project began with an idea provided by Dr. Steve Garnsey, USDA-ARS, retired.

Conduct of the field trials was made possible by the following citrus organizations and individuals and their exceptional long-time commitments of land, tree care, and harvesting assistance: C.E. Crews and Gene Swearingen, grove manager, Avon Park; Arch Updike, Alcoma, Lake Wales; Arthur Thomas, Via Tropical Fruit, Indiantown; and Billie Newell, M\&N Harvesting Co., Dundee, FL; also, Gary Test faithfully helped gather fruit samples and yield data for many years and Dr. Paul Fellers conducted the taste experiments.

${ }^{1}$ To whom reprint requests should be addressed; e-mail bcastle@ufl.edu.
Ridge with Astatula sand soil (Typic Quartzipsamments), a deep, well-drained soil with little organic matter or cation exchange capacity and an acid $\mathrm{pH}$. The Indiantown grove typifies the coastal flatwoods with soils of three series: Riviera and Pineda (Arenic Glossaqualts) and Holopaw (Arenic Ochraqualfs). The dominant soils at the trial are Riviera and Pineda. The soils of these series are Alfisols characterized by an A horizon with $1 \%$ to $5 \%$ organic matter underlain at $\approx 60$ to $90 \mathrm{~cm}$ from the surface by a highly leached B/E horizon of sandy loam to sandy clay loam texture ( $10 \%$ to $25 \%$ clay) that is a natural internal barrier to drainage. Because such sites are poorly drained, their use for citrus requires ditching followed by the forming of two-row beds. The latter process involves cutting furrows and moving soil laterally to form beds between adjacent furrows. Thus, natural variability among soil types and any additional variability resulting from the bedding process are site factors that can have a considerable impact on the variability within a rootstock trial and individual tree performance. In the Indiantown trial, the trial site was ditched only around the perimeter forming a "bed" with 13 rows. The outer rows included soil materials excavated from the ditch. The interior rows were shallow single-row beds; thus, the trees were planted in only lightly disturbed soil.

Trial design and management. The Avon Park trial was planted in a split plot design with four replications of the main plot treatments: commercial preplant fumigation with methyl bromide or no fumigation. That factor was added to the trial because a grove adjacent to the trial was infested with burrowing nematodes (Radopholus similis Cobb). The subplot treatments were 12 rootstocks (Table 1) planted at $4.6 \times 6.1 \mathrm{~m}(358 \mathrm{trees} / \mathrm{ha})$ in sixtree plots (two adjacent rows with three trees in each row). The Indiantown trial was planted in a randomized complete-block design with 10 replications of six-tree plots (like at Avon Park) at $5.1 \times 7.6 \mathrm{~m}$ (252 trees/ha). In addition, two perimeter rows and one in the middle of the trial were planted with six replications of three-tree, in-row plots of rootstock seedlings and rooted cuttings of the scion. Those plants were included to observe their behavior regarding blight along with the budded trial trees.

Each trial was managed according to recommended nutritional, irrigation (microsprinkler), and pest control programs to produce fruit for processing. The annual nitrogen fertilization rate was $\approx 220$ to $250 \mathrm{~kg} \cdot \mathrm{ha}^{-1}$. The Avon Park trees were mechanically hedged generally on an annual cycle; hedging was also done in the Indiantown trial but began later because of the wider spacing at that site. The trees in neither trial were topped in the life of the trials. Several serious freezes occurred during the trial period. The trees were protected with water applied through the irrigation system and did not sustain any damage that required a change in cultural practices or appeared to affect data validity. At Indiantown, trees lost to Phytophthora foot or root rot or citrus blight were replaced annually on the same rootstocks; at Avon Park, trees were also replaced on the same rootstock, but only for $\approx 10$ years on an irregular basis and, thereafter, on other rootstocks.

Data. Tree trunk diameter $15 \mathrm{~cm}$ above the bud union of two trees/plot was measured at planting and annually thereafter. Annual measurement of tree canopy height was added when the trees were $\approx 4$ years old. Trees with blight were recorded in all replicates with diagnosis confirmed by trunk water uptake (Lee et al., 1984). Other annually collected data included yield and juice quality measurement of 60-fruit samples taken from each of six to eight plots. The fruit samples were usually collected in mid to late-March at Avon Park and early May at Indiantown. Juice was extracted and analyzed in an industry standard commercial facility at the University of Florida Citrus Research and Education Center (CREC), Lake Alfred. Yield was measured during commercial harvest by recording volume in standard containers that held $\approx 400 \mathrm{~kg}$ of fruit. Normally, all six trees in a plot were harvested and any diseased or declining trees with salvageable crops were included. When the number of unacceptable trees exceeded three/plot, a substitute plot was selected, or if none was available, then the number of replicates was reduced and the data were analyzed using a missing plot procedure, a situation that arose with only four rootstocks and only required substitutions for one or two plots at both locations.

At Indiantown, the soil was typically more variable then at Avon Park (Bauer et al., 2007) as reflected in plot to plot yield data. Thus, a local USDA-National Resource and Conservation Service soil scientist surveyed the Indiantown location to identify the soils. Soil (0 to $20 \mathrm{~cm}$ deep) and leaf samples were collected from within certain plots according to soil series and rootstocks to study any relationship between tree performance and soil traits. The soil samples were air-dried, extracted with a Mehlich I solution, and analyzed for phosphorus, calcium, and magnesium by atomic absorption spectrometry; $\mathrm{pH}$ was measured in water (2:1 water:soil). Samples of 60 spring flush leaves/plot were collected, washed, dried at $70{ }^{\circ} \mathrm{C}$, and ground for nutrient analysis by atomic absorption; nitrogen was determined by the Keldahl method.

A study of the impact of rootstock on juice flavor was conducted over two consecutive seasons when the trees were 16 and 17 years old. Samples of $400 \mathrm{~kg}$ of fruit were differentially harvested in March by combining fruit from four replicates of trees on Carrizo citrange, Cleopatra mandarin, rough lemon, sour orange, or Swingle citrumelo. Normal fruit samples were collected periodically in advance to track soluble solids:acid ratio. The juice was extracted and analyzed as described previously. Harvest dates were selected when Brix:acid ratios of the fruit from each rootstock were projected to be near 15. The 400-kg samples were washed, sized, and run through a commercial extractor at CREC, Lake Alfred. The juice was passed 
Table 1. Height and survival of 'Valencia' orange trees on 12 rootstocks grown at Avon Park (AP; $n=8)$ or Indiantown ( $\mathrm{I} ; \mathrm{n}=6)$, FL.

\begin{tabular}{|c|c|c|c|c|c|c|}
\hline \multirow[b]{3}{*}{ Rootstock } & \multicolumn{4}{|c|}{ Tree ht $(\mathrm{m})$ at } & \multirow{2}{*}{\multicolumn{2}{|c|}{ Survival $(\%)^{2}$}} \\
\hline & \multicolumn{2}{|c|}{$5 \mathrm{yr}$} & \multicolumn{2}{|c|}{$11 \mathrm{yr}$} & & \\
\hline & $\overline{\mathrm{AP}}$ & I & $\overline{\mathrm{AP}}$ & I & $\overline{\mathrm{AP}}$ & I \\
\hline Carrizo citrange & 3.1 & 3.0 & 4.5 & 4.1 & 69 & 45 \\
\hline Citrus sinensis (L.) Osb. $\times$ Poncirn & trifo & L. $(\mathrm{R}$ & & & & \\
\hline $\begin{array}{l}\text { Cleopatra mandarin } \\
\text { C. reticulata } \text { Blanco }\end{array}$ & 2.9 & 3.1 & 4.5 & 4.4 & 65 & 27 \\
\hline $\begin{array}{l}\text { Macrophylla } \\
\text { C. macrophylla Wester }\end{array}$ & 2.6 & 3.0 & 3.8 & 3.7 & 77 & \\
\hline $\begin{array}{l}\text { Orlando tangelo } \\
\quad \text { C. paradisi } \text { Macf. } \times \text { C. reticulata }\end{array}$ & 2.6 & 3.3 & 4.4 & 4.6 & 83 & \\
\hline $\begin{array}{l}\text { Palestine sweet lime } \\
\text { C. limettioides Tan. }\end{array}$ & 2.9 & 3.1 & 4.2 & 3.7 & 63 & \\
\hline $\begin{array}{l}\text { Rangpur } \\
\quad \text { C. limonia Osb. }\end{array}$ & 2.8 & 3.0 & 4.3 & 4.1 & 60 & \\
\hline $\begin{array}{l}\text { Rough lemon } \\
\text { C. jambhiri Lush. }\end{array}$ & 2.9 & 3.4 & 4.3 & 4.6 & 46 & \\
\hline $\begin{array}{l}\text { Sour orange } \\
\text { C. aurantium } \mathrm{L} \text {. }\end{array}$ & 2.8 & 2.9 & 4.4 & 4.3 & 96 & \\
\hline $\begin{array}{l}\text { Sweet orange } \\
\quad \text { C. sinensis }\end{array}$ & 2.2 & 2.9 & 4.0 & 4.1 & 90 & \\
\hline $\begin{array}{l}\text { Swingle citrumelo } \\
\quad \text { C. paradisi } \times P \text {. trifoliata }\end{array}$ & 2.3 & 2.6 & 3.6 & 3.6 & 98 & \\
\hline $\begin{array}{l}\text { Trifoliate orange } \\
\quad \text { P. trifoliata }\end{array}$ & 2.4 & 2.9 & 3.5 & 3.7 & 75 & \\
\hline $\begin{array}{l}\text { Volkamer lemon } \\
\text { C. volkameriana. Ten. \& Pasq. }\end{array}$ & 3.1 & 3.5 & 4.7 & 4.7 & 44 & \\
\hline Valencia sweet orange cuttings ${ }^{\mathrm{y}}$ & & & & 3.8 & & \\
\hline Mean & 2.7 & 3.1 & 4.2 & 4.1 & 72 & \\
\hline Least significant difference & 0.2 & 0.2 & 0.2 & 0.3 & & \\
\hline
\end{tabular}

${ }^{\mathrm{z}}$ After 24 years at Avon Park and 27 years at Indiantown.

${ }^{\mathrm{y}}$ Excluded from statistical analysis.

through a finisher, pasteurized, filled into 177-mL tin cans, and then stored frozen until use. Samples were removed from storage, brought to $15.5^{\circ} \mathrm{C}$, and presented to $\approx 15$ to 18 experienced panelists familiar with tasting citrus juices. The juices were rated on a hedonic scale of $1=$ dislike extremely, $5=$ neither like nor dislike, and $9=$ like extremely (Kramer, 1960).

Statistical analyses. Statistical comparisons were not made between locations. Data were analyzed within a location according to the trial design using PROC GLM (SAS Institute, Cary, NC) with mean separation by the least significant difference (LSD) method. Yield data at both locations were analyzed each year. The Indiantown yield data were also examined using a repeated-measures analysis to determine yield trends. Citrus fruit yield has two components: tree growth over time and the associated increase in yield, and annual yield variation resulting from environmental factors (weather). Data plots indicated yield with tree age could be represented by a quadratic curve, but the quadratic effect on yield in relation to tree age was not statistically significant. The measurable yield trend with time was linear and interacted $(P<0.0001)$ with rootstock. The slopes of the yield regressions were calculated and compared by the LSD method. Mean flavor data were compared using rank sums for multiple comparisons (Kramer, 1960).

Economic interpretation. Data analyses were conducted using prevailing industry costs and returns during the 1980s when the trial was conducted (all financial assumptions and cost and return numbers are available from R.P. Muraro). Annual yields, tree losses with annual replacement of trees on the same rootstocks (virtually all tree losses were from citrus blight), and juice quality data from both trials were used to calculate annual net operating income and annual and cumulative cash flows for trees on the seven commercial rootstocks among the 12 rootstocks in the trials. The calculation assumed that replacement trees grew and yielded the same as the original trees. That assumption is based on observation, occasional measurement of tree height, and yield estimates at both locations. To address the time value of money, a discount rate (because $\$ 1$ today is worth more than $\$ 1$ received in future years) of $15 \%$ was used for the cash flow calculations and estimated internal rates of return. The outcomes are based on hypothetical 1-ha groves in three scenarios with trees planted at their respective trial spacing: 1) no tree loss; 2) actual tree loss with no replacement; and 3) actual tree loss with replacement (Muraro and Castle, 1996); and certain other hypothetical tree spacing situations deemed reasonable from observations of tree development and final canopy size during the course of the trials. The financial outcomes included ending grove value.

\section{Results and Discussion}

Tree growth and survival. After 5 years, the trees at both locations on all rootstocks were nearly the same height, $\approx 3 \mathrm{~m}$; however, some significant differences were beginning to appear among rootstocks (Table 1). The shortest trees at both locations were those on
Swingle citrumelo $(\approx 2.5 \mathrm{~m})$ and the tallest ones were those on Volkamer lemon $(\approx 3.3$ $\mathrm{m})$. After 11 years, mean tree heights had increased to $\approx 4 \mathrm{~m}$, but again with little difference between locations. The shortest trees at both locations $(\approx 3.5 \mathrm{~m})$ were those on Swingle citrumelo, trifoliate orange, and macrophylla; the tallest trees at $4.7 \mathrm{~m}$ were those on Volkamer lemon. Changes in trunk cross-sectional area essentially showed the same relationships among rootstocks and locations (Fig. 1). At Avon Park, the trees growing in the portion of the trial site that received preplant fumigation were significantly larger in the first year than those that received no fumigation; however, the fumigation main effect was small and disappeared within the next 2 years. Fumigation was not a significant factor in tree survival, fruit yield, or juice quality and is not considered here. The 'Valencia' (scion) cuttings were among the smaller plants at the Indiantown location.

Most tree losses were from citrus blight, a disorder of unknown cause in which a tree loses xylem function and declines (Derrick and Timmer, 2000). In the first 2 years, 11 of the trees on sweet orange rootstock $(18 \%)$ were lost to Phytophthora and less than $10 \%$ each among the trees on rough lemon or Volkamer lemon. Thereafter, all tree losses were from blight. Tree survival was strongly affected by rootstock and the pattern of tree losses was different between locations (Table 1 ; Fig. 2). After $\approx 25$ years, the survival at both locations ranged from less than $46 \%$ among trees on Volkamer lemon and rough lemon to greater than $80 \%$ among those on sweet and sour oranges. Blight was more severe at Indiantown where after 27 years, only $40 \%$ or less of the original trees survived on six rootstocks, whereas at Avon Park, tree survival was greater than $60 \%$ on all but two rootstocks.

Tree decline from blight was first observed at Indiantown when the trees were 5 to 6 years old and preceded any decline at Avon Park by 2 years. At Indiantown, the trees on Volkamer lemon were among the first to show blight symptoms. Tree loss thereafter occurred at a relatively steep largely linear rate for more than 18 years before appearing to halt for a few years. That pattern was similar at Avon Park where tree loss was lower (Fig. 2). Tree loss on Cleopatra mandarin at both locations was low for $\approx 12$ years and then accelerated at different rates between locations leading to a higher survival at Avon Park. The trees on Swingle citrumelo also had low rates of loss that extended to more than 20 years; however, there was a clear location effect. Tree loss at Avon Park remained low and $98 \%$ of the trees survived, whereas at Indiantown, tree loss increased over time and only $63 \%$ of the original 60 trees survived. The pattern of tree loss was also highly variable within a location and rootstock. There were six-tree plots at both locations that survived completely intact for years beyond when blight appeared in other plots on the same rootstocks. There were also plots in which all the trees became 


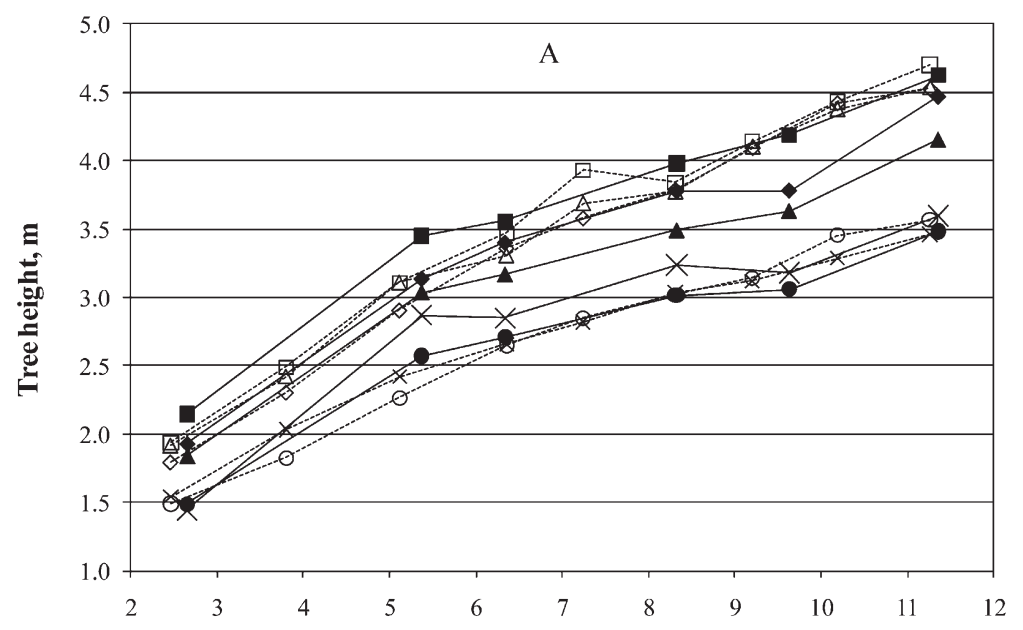

Tree age, yrs.

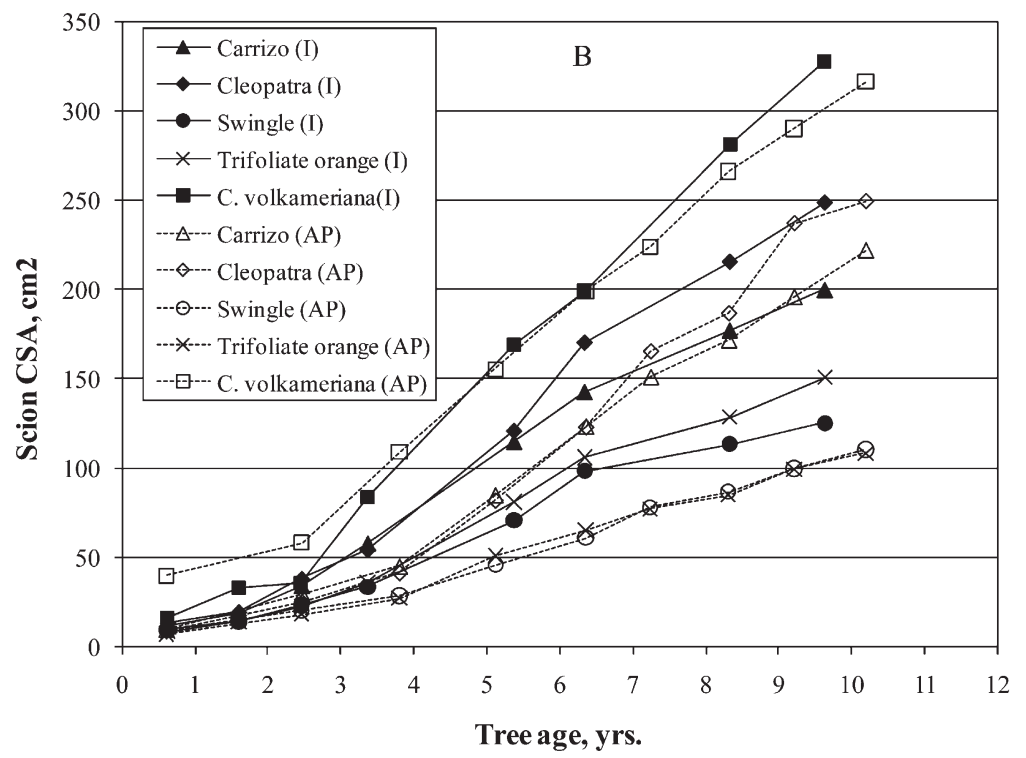

Fig. 1. Tree height (A) and trunk cross-sectional area (B) growth among 'Valencia' orange trees on five of 12 rootstocks in two field trials planted at 358 trees/ha at Avon Park (AP) or 252 trees/ha at Indiantown (I), FL.

blighted before any were affected in other plots indicating the nonrandom development of blight, which has been previously reported but remains unexplained (Derrick and Timmer, 2000). Replanting in a space where a tree was removed because of blight did not seem to accelerate decline. The incidence of blight among replacement trees was very similar to the pattern experienced with the original trees. Replacement trees on Volkamer lemon and rough lemon began to decline $\approx 8$ years after planting and those on Cleopatra mandarin started to decline from blight after 12 years.

Cuttings of the 'Valencia' scion were only included at Indiantown. Much like the trees budded on sweet orange rootstock, the cuttings survived many years with virtually no loss to blight; however, some cuttings declined later and their survival was only $64 \%$ as compared with $84 \%$ for the trees budded on sweet orange rootstock. The cuttings were mostly planted along the perimeter of the trial where the spoil from adjacent ditches may have influenced their survival, but their growth and yield appeared to be no more variable than among the budded trees.

Yield and juice quality. All trees began to produce measureable crops within 2 years after planting (Table 2). In Year 2, yield was generally higher at Avon Park where the trees on macrophylla, Palestine sweet lime, Rangpur, rough lemon, and Volkamer lemon produced $\approx 40 \mathrm{~kg} /$ tree and most other trees at both locations produced less than $10 \mathrm{~kg} /$ tree. The relationships among rootstocks were established early and the trend was largely unchanged after 14 years. There were significant differences within location and among rootstocks in each of the years that yield was measured. The highest cumulative yields (one young tree yield was missed at Avon Park) were 2176 and $2573 \mathrm{~kg}$ for trees on Volkamer lemon at Avon Park and Indiantown, respectively. Yield generally increased with tree age, but fluctuated annually after the trees were $\approx 8$ years old, which is normal for Valencia in Florida (Castle and Baldwin, 1995; Castle et al., 1993; Florida Agricultural Statistics
Service, 2009). The highest peak yields were among the trees on Volkamer lemon, which exceeded $300 \mathrm{~kg} /$ tree. Other trees at both locations with relatively high cumulative and annual yields were those on rough lemon followed by Rangpur, Palestine sweet lime, macrophylla, and Carrizo citrange (range, 1800 to $2528 \mathrm{~kg} /$ tree). Those trees commonly produced between 200 and $300 \mathrm{~kg} /$ tree annually after they were $\approx 7$ years old. The trees on other rootstocks such as trifoliate orange, Swingle citrumelo, and sour orange generally yielded 50 to $100 \mathrm{~kg}$ less/tree annually leading to cumulative yields at both locations that were between $\approx 1100$ and $1500 \mathrm{~kg} /$ tree. The yield of the cuttings was often similar to or lower than yield of the budded trees.

Yield trends over time have rarely been statistically examined in citrus rootstock trials (Bevington and Cullis, 1990). Repeatedmeasures analysis among the Indiantown trees showed yield increased over time at significantly different rates among trees on 12 rootstocks as indicated by the slopes of the regression lines (Table 3 ). The trend over time was linear meaning that yield continued to increase as the trees increased in size regardless of rootstock. Trees on those rootstocks with the most vigor like rough lemon and Volkamer lemon had the largest annual increase in yield; trees on Swingle citrumelo and trifoliate orange had the smallest increase.

The juice quality data are presented in 2year means for young (Years 5 to 6), middleaged (Years 9 to 10), and mature (Years 13 to 14) trees and for years unaffected by freezes (Table 4). Using 2-year means helped reduce year-to-year seasonal and sampling variability. Typical juice contents among rootstocks were $\approx 56 \%$ to $61 \%$ with significant differences among rootstocks, but only small differences between locations at any tree age. Juice content increased as the trees matured, especially at Indiantown where the mean value increased from $56.4 \%$ to $63.3 \%$. Fruit soluble solids concentrations among trees on Volkamer lemon, rough lemon, macrophylla, and Palestine sweet line constituted a group with relatively lower values; the highest values were for the trees on trifoliate orange and the 'Valencia' cuttings $(11.6 \%$ to $13.8 \%$ ). Soluble solids concentration tended to be higher among the Indiantown trees than those at Avon Park and increased with tree age at Avon Park but was less consistent at Indiantown. The difference is largely the result of the later annual sampling time (May versus March) at Indiantown and not location. The fruit from trees on rootstocks with low soluble solids also had lower acid values and the fruit from those trees on those rootstocks with high soluble solids, like sour orange and trifoliate orange, had significantly higher acid values. Soluble solids-acid ratio is a measure of fruit maturity. Fruit with lower ratios mature later than those with higher ratios. There were significant differences in each age group within locations. High soluble solids fruit such as those from trees on sour orange and trifoliate orange had higher acidity and lower ratios. 

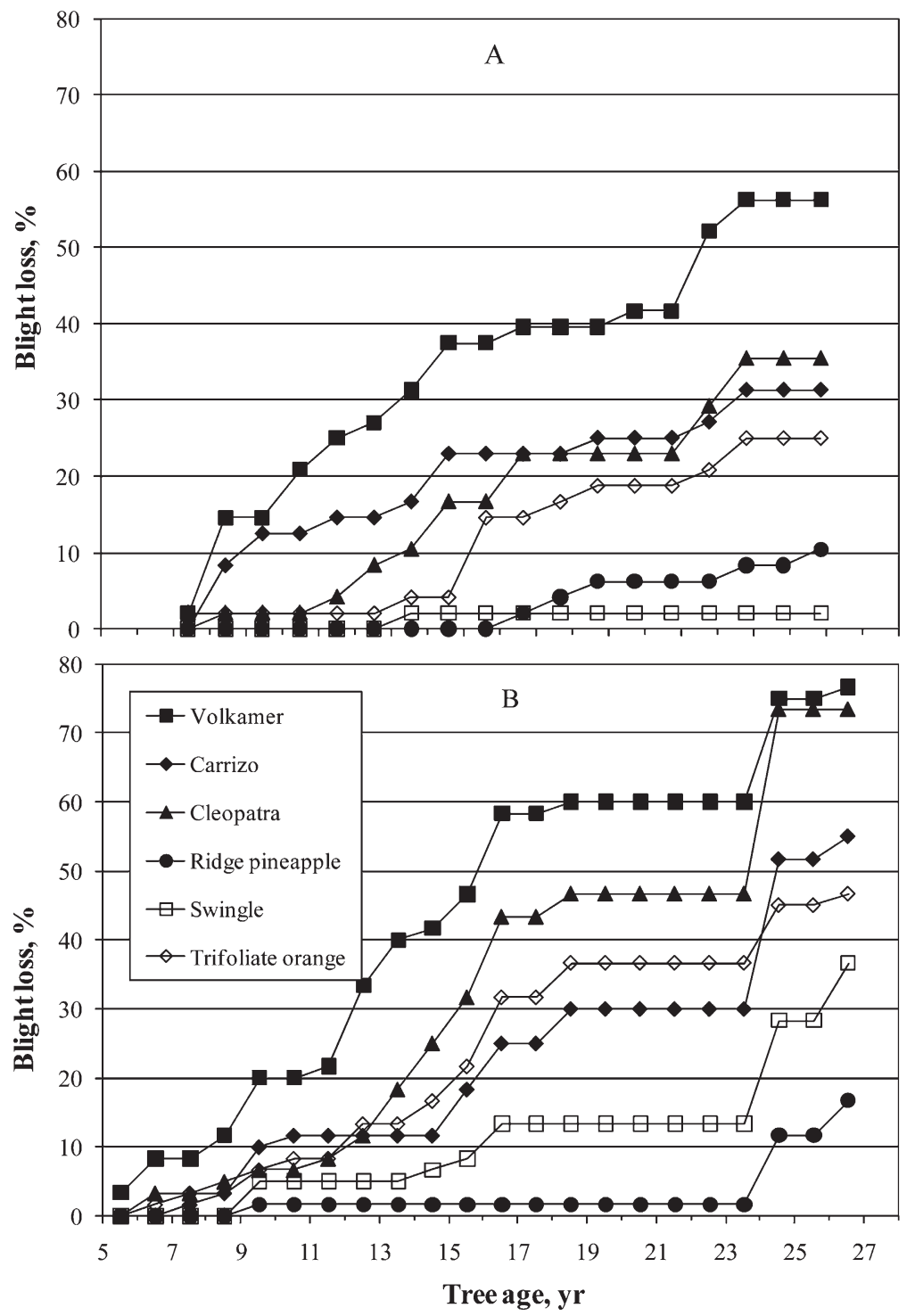

Fig. 2. Cumulative blight loss among 'Valencia' orange trees on five of 12 rootstocks in two field trials planted at Indiantown (A) or Avon Park (B), FL.

The main differences among rootstocks largely carried through when all the juice factors were combined into the soluble solids/ha calculations (Table 4). That variable is important to growers of fruit for juice because it is the basis for payment by the processor and, thus, determines income. The highest producers of soluble solids/ha were the trees on those rootstocks (Volkamer lemon, and so on) that produced fruit with relatively low-quality juice, but had the highest fruit yields. The high soluble solids concentrations in fruit from trees on rootstocks like sour orange did not compensate for their lower productivity. Trees on Volkamer lemon yielded 6000 to $7000 \mathrm{~kg}$ of soluble solids/ha in Year 13 to 14 at Indiantown and Avon Park, respectively, whereas those on trifoliate orange produced less than $4600 \mathrm{~kg}$ at either location. However, the quantities of soluble solids produced at Avon Park were higher than at Indiantown because of the difference in tree planting density, which was higher at Avon Park. The cuttings had among the best juice quality values, but their lower yields resulted in the lowest soluble solids production/ha. were not able to distinguish differences over two seasons among pasteurized 'Valencia' stocks and normalized by soluble solids:acid ratio. The hedonic scores indicated that all juices had acceptable flavor, although the juices from the trees on rough lemon had typically low soluble solids and those on sour orange had one of the highest values (Table 5). These results contradict the conventional view that trees on rough lemon produce low-quality juice as compared with those on sour orange. Seasonal sampling data show that the soluble solids difference between the two rootstocks would occur almost all season-long, but changes in acid do not occur at the same rate; thus, there are times when ratios are similar and taste differences apparently become difficult to separate. Flavor of orange juice products is important in Florida where a 100-point
Juice flavor. The experienced panelists juices produced from trees on different root- scoring system is used commercially and 40 points are assigned to flavor for Grade A products (Fellers, 1990). The implication of our results is that growers producing fruit for juice with trees on different rootstocks harvested according to ratio might benefit with better returns; likewise, processors might have blending options with such fruit.

Yield variability among replications. In comparing high- and low-yielding individual replicates within trees on four commercial rootstocks in the trial at Indiantown, tree height of the low-yielding replicates tended to be smaller after 14 years, but cumulative yield was $30 \%$ to $200 \%$ larger in the more productive replicates (Table 6). The yield differences between replicates within rootstocks were meaningful and, in all cases, were established when the trees were young and generally continued for their recorded lifetimes (Fig. 3). Furthermore, 'Valencia' typically alternate bears in Florida (Florida Agricultural Statistics Service, 2009), but that tendency seemed to be reduced among the low-yielding replicates.

The differences within rootstocks suggest that soil factors were affecting tree nutrition and yield but not tree growth. A professional assessment of the soil variability and series present at the site reinforces the relationship of rootstock performance to certain soil features such as the presence of, and depth to, an argillic (clay) horizon, presence of calcareous materials, soil organic matter content, and texture (Mann et al., 2009). Tree performance was adversely affected when one or more of these soil traits were present like in all the low-yielding replicates, which had an argillic horizon of sandy clay or sandy clay loam texture present at $\approx 40$ to $70 \mathrm{~cm}$. The high-yielding replicates were all growing in Pineda soils, which are considered among the best for citrus in the coastal flatwoods areas of Florida. Pineda soils also have an argillic horizon, but it occurred at the trial location at depths greater than $80 \mathrm{~cm}$. The coated sand grains in Pineda soils have been shown to have a positive influence on tree yield (Mann et al., 2009). Excessive amounts of phosphorus (particularly in the 0 - to $15-\mathrm{cm}$ sample) and calcium were found in the soil samples. The calcium contents are well above the level considered adequate probably because of the strong extractant used in processing the soil samples (Obreza and Morgan, 2008); however, in most instances, the quantities reported at both sample depths in the low-yielding replicates exceeded those at both depths in the highyielding replicates. The high soil phosphorus and calcium levels were reflected in the high leaf nutrient concentration data for phosphorus and calcium combined over 2 consecutive years of sampling (Table 4). Other leaf nutrient concentrations were optimum or near optimum except for zinc. Severe leaf zinc deficiency was observed for many years among the trees growing in the poorer performing replicates and less so in the other replicates. Chronic zinc deficiency can reduce yield (Obreza and Morgan, 2008). 
Table 2. Yield (kg/tree) of 'Valencia' orange trees on 12 rootstocks at Avon Park (AP; $\mathrm{n}=8)$ and Indiantown ( $\mathrm{I} ; \mathrm{n}=6)$, FL.

\begin{tabular}{|c|c|c|c|c|c|c|c|c|c|c|c|c|c|c|}
\hline \multirow[b]{2}{*}{ Rootstock } & \multicolumn{14}{|c|}{ Tree age (yrs) } \\
\hline & 2 & 3 & 4 & 5 & 6 & 7 & 8 & 9 & 10 & 11 & 12 & 13 & 14 & $\overline{\text { Cumulative }}$ \\
\hline \multicolumn{15}{|c|}{ Carrizo citrange } \\
\hline AP & 10 & 51 & $0^{\mathrm{z}}$ & 76 & 120 & 80 & 230 & 122 & 245 & 188 & 231 & 295 & 267 & $1912^{\mathrm{z}}$ \\
\hline I & 7 & 12 & 35 & 70 & 90 & 122 & 187 & 161 & 187 & 161 & 255 & 255 & 216 & 1759 \\
\hline \multicolumn{15}{|c|}{ Cleopatra mandarin } \\
\hline $\mathrm{AP}$ & 1 & 32 & 0 & 38 & 73 & 71 & 167 & 167 & 193 & 209 & 115 & 278 & 198 & 1540 \\
\hline I & 1 & 4 & 26 & 40 & 68 & 108 & 177 & 161 & 162 & 122 & 246 & 225 & 190 & 1531 \\
\hline \multicolumn{15}{|c|}{ Citrus macrophylla } \\
\hline AP & 41 & 55 & 0 & 48 & 104 & 59 & 237 & 169 & 235 & 164 & 233 & 228 & 228 & 1800 \\
\hline I & 8 & 22 & 49 & 60 & 129 & 145 & 210 & 172 & 201 & 189 & 228 & 247 & 213 & 1872 \\
\hline \multicolumn{15}{|c|}{ Orlando tangelo } \\
\hline AP & 2 & 33 & 0 & 37 & 51 & 45 & 151 & 131 & 201 & 186 & 130 & 228 & 167 & 1361 \\
\hline I & 5 & 3 & 34 & 54 & 90 & 119 & 197 & 177 & 197 & 145 & 268 & 255 & 209 & 1753 \\
\hline \multicolumn{15}{|c|}{ Palestine sweet lime } \\
\hline AP & 38 & 74 & 0 & 97 & 132 & 38 & 281 & 112 & 270 & 191 & 269 & 226 & 281 & 2010 \\
\hline I & 6 & 22 & 58 & 100 & 129 & 154 & 202 & 153 & 198 & 163 & 270 & 228 & 288 & 1971 \\
\hline \multicolumn{15}{|l|}{ Rangpur } \\
\hline $\mathrm{AP}$ & 37 & 69 & 0 & 74 & 110 & 91 & 232 & 168 & 243 & 207 & 213 & 272 & 232 & 1946 \\
\hline I & 6 & 21 & 46 & 103 & 116 & 166 & 215 & 189 & 219 & 196 & 281 & 293 & 245 & 2097 \\
\hline \multicolumn{15}{|c|}{ Rough lemon } \\
\hline $\mathrm{AP}$ & 29 & 61 & 0 & 41 & 123 & 57 & 253 & 181 & 273 & 214 & 236 & 259 & 239 & 1964 \\
\hline I & 7 & 19 & 66 & 101 & 152 & 176 & 232 & 269 & 250 & 250 & 293 & 391 & 325 & 2528 \\
\hline \multicolumn{15}{|c|}{ Sour orange } \\
\hline AP & 8 & 46 & 0 & 59 & 76 & 62 & 189 & 127 & 207 & 194 & 155 & 248 & 208 & 1581 \\
\hline I & 3 & 8 & 22 & 41 & 74 & 100 & 154 & 104 & 169 & 139 & 221 & 253 & 187 & 1475 \\
\hline \multicolumn{15}{|c|}{ Swingle citrumelo } \\
\hline $\mathrm{AP}$ & 10 & 40 & 0 & 55 & 65 & 69 & 133 & 109 & 166 & 159 & 153 & 164 & 160 & 1281 \\
\hline I & 3 & 11 & 20 & 40 & 66 & 91 & 145 & 96 & 123 & 104 & 188 & 182 & 123 & 1191 \\
\hline \multicolumn{15}{|c|}{ Sweet orange } \\
\hline AP & 8 & 25 & 0 & 21 & 41 & 44 & 138 & 126 & 193 & 189 & 131 & 230 & 203 & 1349 \\
\hline I & 5 & 7 & 25 & 38 & 91 & 107 & 181 & 142 & 185 & 131 & 227 & 243 & 225 & 1606 \\
\hline \multicolumn{15}{|c|}{ Trifoliate orange } \\
\hline AP & 12 & 42 & 0 & 67 & 71 & 101 & 140 & 133 & 153 & 160 & 167 & 148 & 164 & 1357 \\
\hline I & 5 & 9 & 21 & 32 & 85 & 98 & 126 & 128 & 143 & 121 & 182 & 206 & 177 & 1332 \\
\hline \multicolumn{15}{|c|}{ Volkamer lemon } \\
\hline AP & 41 & 77 & 0 & 96 & 149 & 55 & 283 & 185 & 258 & 208 & 224 & 334 & 265 & 2176 \\
\hline I & 8 & 24 & 59 & 121 & 150 & 184 & 251 & 235 & 225 & 242 & 356 & 364 & 355 & 2573 \\
\hline Valencia c & & & & & 43 & 74 & & 108 & 156 & 112 & 223 & 182 & 158 & 1057 \\
\hline \multicolumn{15}{|c|}{ Least significant difference } \\
\hline $\mathrm{AP}$ & 5 & 11 & & 25 & 18 & 23 & 27 & 27 & 30 & 29 & 30 & 45 & 55 & \\
\hline $\mathrm{I}$ & 4 & 6 & 13 & 19 & 28 & 25 & 29 & 31 & 52 & 30 & 39 & 56 & 58 & \\
\hline
\end{tabular}

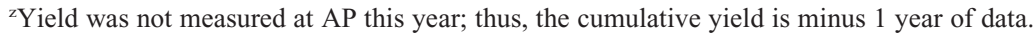

${ }^{\mathrm{y}}$ Excluded from statistical analysis.

A recent, comprehensive study showed that Florida citrus yield can be significantly related through several statistical methods to various soil properties (Mann et al., 2009). In our study at Indiantown, the magnitude and consistency of the yield differences within rootstocks revealed and confirmed sitespecific soil factors that would be useful in selecting sites for particular rootstocks. The best examples are Carrizo citrange and Swingle citrumelo. They are hybrids of trifoliate orange, a rootstock well known for intolerance to high levels of soil calcium that can result in calcium-induced iron chlorosis and nutrient imbalances and deficiencies that affect tree growth and cropping (Castle, 1987; Castle et al., 2009; Obreza and Morgan, 2008). Calcareous materials and high $\mathrm{pH}$ contributed to the differential performance among the high- and low-yielding plots of trees on those rootstocks.

A further consideration is whether the differences among replicates compromised the statistical validity of the Indiantown trial. Site variability is normally accounted for by blocking when establishing a field trial. The estimates of variability for blocks were not
Table 3. A repeated-measures analysis of yield trends over 10 years among 'Valencia' trees planted on 12 rootstocks $(n=6)$ in 1976 at Indiantown, FL.

\begin{tabular}{lcc}
\hline Rootstock & $\begin{array}{c}\text { Slope of regression } \\
\text { line }\end{array}$ & $R^{2}$ \\
\hline Carrizo citrange & $19.9 \mathrm{bc}^{\mathrm{y}}$ & 0.77 \\
Citrus macrophylla & $18.2 \mathrm{~cd}$ & 0.70 \\
Cleopatra mandarin & $15.8 \mathrm{~cd}$ & 0.72 \\
Orlando tangelo & $18.4 \mathrm{~cd}$ & 0.70 \\
Palestine sweet lime & $17.5 \mathrm{~cd}$ & 0.76 \\
Rangpur lime & $19.5 \mathrm{c}$ & 0.78 \\
Rough lemon & $27.0 \mathrm{a}$ & 0.85 \\
Sour orange & $19.8 \mathrm{bc}$ & 0.74 \\
Swingle citrumelo & $12.5 \mathrm{~d}$ & 0.59 \\
Sweet orange & $26.6 \mathrm{ab}$ & 0.70 \\
Trifoliate orange & $15.7 \mathrm{~cd}$ & 0.82 \\
Volkamer lemon & $27.9 \mathrm{a}$ & 0.88 \\
\hline
\end{tabular}

${ }^{\mathrm{z}} \mathrm{Y}=\mathrm{a}+\mathrm{bX}$ where $\mathrm{X}=$ tree age (years).

${ }^{\mathrm{y}}$ Mean separation by least significant difference method; $\mathrm{LSD}=6.9$.

(Carrizo citrange) to $\$ 9,868$ (Ridge Pineapple sweet orange) (Table 7). Cash flows decreased substantially in the second scenario of blight losses in the trials with no tree replacement, except among the trees on those rootstocks with little or no blight loss, e.g., sour orange and Swingle citrumelo; however, at Indiantown, the cash flow for the trees on Swingle citrumelo changed from a positive to negative value and the returns would probably have improved further if the trees had been planted on more suitable soil (Table 6).

By replacing lost trees with another tree on the same rootstock, cash flow at Indiantown increased by comparison with the no replacement scenario, particularly among those rootstocks like Volkamer lemon that had the highest losses; at Avon Park, there was little change. The trees on Swingle citrumelo at Indiantown had a negative cash flow even when trees lost to blight were replaced. Negative cash flows mean that incomes did not exceed the $15 \%$ profit level we selected for the financial calculations. When the planting density at Indiantown for the trees on Swingle citrumelo was adjusted to the same as at Avon Park (358 trees/ha), cash flow improved to greater than $\$ 5000 / \mathrm{h}$.

Internal rates of return (IRR) tracked the cash flows and ranged from $14 \%$ to $29 \%$. During the period of the trials, there were no particularly high production or harvesting costs, but juice prices paid by processors were historically high; thus, the IRRs were above normal for agricultural investments (Bierman and Smidt, 2006).

Financial interpretation, rootstock selection, and planting density. Rootstock evaluation normally relies on common measures of horticultural performance like tree growth, productivity, and fruit and juice quality. Rootstock selection decisions based just on those traits do not take into account differences in the relative value or contribution of each rootstock attribute. Financial evaluation of horticultural performance integrates all biological and economic factors affecting the outcomes of an orchard on a particular rootstock and, thus, is a better means of assessment. We showed, e.g., that 
Table 4. Juice quality of fruit harvested from 'Valencia' orange trees on 12 rootstocks $(n=6)$ grown at Avon Park (AP) and Indiantown (I), FL.

\begin{tabular}{|c|c|c|c|c|c|c|c|c|c|c|c|}
\hline \multirow[b]{2}{*}{ Rootstock } & \multirow{2}{*}{$\begin{array}{l}\text { Tree } \\
\text { age } \\
(\mathrm{yrs})^{z}\end{array}$} & \multicolumn{2}{|c|}{$\begin{array}{c}\text { Juice } \\
\text { content }(\%)\end{array}$} & \multicolumn{2}{|c|}{$\begin{array}{c}\text { Soluble } \\
\text { solids } \\
\text { concn (\%) }\end{array}$} & \multicolumn{2}{|c|}{$\begin{array}{c}\text { Acid } \\
(\%)\end{array}$} & \multicolumn{2}{|c|}{$\begin{array}{l}\mathrm{SS} / \mathrm{A} \\
\text { ratio }\end{array}$} & \multicolumn{2}{|c|}{$\begin{array}{l}\text { Soluble } \\
\text { solids } \\
\left(\mathrm{kg} \cdot \mathrm{ha}^{-1}\right)^{\mathrm{y}}\end{array}$} \\
\hline & & AP & $\mathrm{I}$ & $\mathrm{AP}$ & I & $\overline{\mathrm{AP}}$ & I & $\overline{\mathrm{AP}}$ & I & $\mathrm{AP}$ & I \\
\hline \multirow{3}{*}{$\begin{array}{l}\text { Carrizo } \\
\text { citrange }\end{array}$} & $5-6$ & 58.1 & 56.7 & 11.4 & 12.2 & 0.96 & 0.72 & 12.0 & 17.8 & 2317 & 134 \\
\hline & $9-10$ & 58.9 & 61.3 & 11.8 & 13.5 & 0.93 & 0.84 & 12.8 & 16.3 & 4555 & 364 \\
\hline & $13-14$ & 59.1 & 63.7 & 12.9 & 12.2 & 0.91 & 0.75 & 14.3 & 16.4 & 7647 & 493 \\
\hline \multirow{3}{*}{$\begin{array}{l}\text { Cleopatra } \\
\text { mandarin }\end{array}$} & $5-6$ & 59.0 & 59.9 & 11.1 & 11.9 & 0.97 & 0.74 & 11.5 & 16.5 & 1299 & 94 \\
\hline & $9-10$ & 60.8 & 61.7 & 11.5 & 13.1 & 0.93 & 0.88 & 12.4 & 14.9 & 4499 & 307 \\
\hline & $13-14$ & 60.1 & 64.3 & 12.6 & 11.7 & 0.93 & 0.76 & 13.7 & 15.6 & 6417 & 389 \\
\hline \multirow[t]{3}{*}{ C. macrophylla } & $5-6$ & 53.7 & 47.1 & 9.8 & 10.3 & 0.85 & 0.62 & 11.7 & 18.0 & 1418 & 118 \\
\hline & $9-10$ & 57.2 & 60.1 & 10.9 & 11.7 & 0.89 & 0.74 & 12.3 & 15.9 & 4504 & 325 \\
\hline & $13-14$ & 59.2 & 62.7 & 13.1 & 11.6 & 93 & 0.70 & 14.4 & 16.6 & 6328 & 422 \\
\hline \multirow{3}{*}{$\begin{array}{l}\text { Orlando } \\
\text { tangelo }\end{array}$} & $5-6$ & 57.8 & 60.3 & 11.1 & 12.2 & 0.98 & 0.77 & 11.4 & 16.3 & 1012 & 136 \\
\hline & $9-10$ & 59.9 & 62.3 & 11.5 & 12.9 & 0.89 & 0.86 & 13.0 & 15.1 & 4097 & 386 \\
\hline & $13-14$ & 59.8 & 63.6 & 12.5 & 11.8 & 0.94 & 0.78 & 13.5 & 15.3 & 5294 & 438 \\
\hline \multirow{3}{*}{$\begin{array}{l}\text { Palestine } \\
\text { sweet lime }\end{array}$} & $5-6$ & 54.8 & 57.5 & 9.9 & 11.8 & 0.86 & 0.75 & 11.6 & 16.1 & 2225 & 197 \\
\hline & $9-10$ & 57.5 & 60.4 & 10.6 & 12.4 & 0.89 & 0.79 & 12.0 & 15.8 & 4185 & 337 \\
\hline & $13-14$ & 59.9 & 63.4 & 12.4 & 11.6 & 0.88 & 0.73 & 14.2 & 15.9 & 6737 & 492 \\
\hline \multirow[t]{3}{*}{ Rangpur } & $5-6$ & 56.7 & 56.0 & 10.2 & 10.9 & 0.88 & 0.66 & 11.7 & 17.2 & 1892 & 170 \\
\hline & $9-10$ & 58.9 & 61.0 & 11.0 & 12.0 & 0.88 & 0.77 & 12.6 & 15.6 & 4785 & 383 \\
\hline & $13-14$ & & 62.6 & .5 & 11.0 & & 0.67 & 15.2 & 16.5 & 6897 & 472 \\
\hline \multirow[t]{3}{*}{ Rough lemon } & $5-6$ & 54.9 & 53.0 & 10.0 & 10.8 & 0.85 & 0.67 & 11.8 & 17.0 & 1605 & 175 \\
\hline & $9-10$ & 58.3 & 60.3 & 11.2 & 12.1 & 0.91 & 0.79 & 12.3 & 15.3 & 5307 & 475 \\
\hline & $13-14$ & 59.7 & 61.1 & 12.5 & 10.8 & 0.91 & 0.69 & 13.9 & 15.8 & 6664 & 601 \\
\hline \multirow[t]{3}{*}{ Sour orange } & $5-6$ & 59.6 & 59.9 & 11.4 & 12.3 & 1.02 & 0.77 & 11.2 & 16.7 & 1640 & 110 \\
\hline & $9-10$ & 60.6 & 60.8 & 1.7 & 13.3 & 94 & 0.94 & 12.6 & 14.3 & 4248 & 284 \\
\hline & $13-14$ & & 64.2 & & 12.1 & & 0.79 & 13.1 & 15.3 & 6272 & 453 \\
\hline \multirow[t]{3}{*}{ Sweet orange } & $5-6$ & 56.7 & 57.9 & 10.7 & 11.3 & 0.92 & 0.66 & 11.7 & 18.4 & 673 & 109 \\
\hline & $9-10$ & 59.4 & 61.1 & 11.7 & 13.1 & 0.89 & 0.91 & 13.3 & 14.6 & 3964 & 3300 \\
\hline & $13-14$ & 59.1 & 64.7 & 12.7 & 11.8 & 0.89 & 0.76 & 14.4 & 15.6 & 5803 & 4721 \\
\hline \multirow{3}{*}{$\begin{array}{l}\text { Swingle } \\
\text { citrumelo }\end{array}$} & $5-6$ & 59.0 & 58.7 & 11.5 & 11.9 & 0.97 & 0.72 & 12.0 & 16.4 & 1454 & 909 \\
\hline & $9-1$ & & 59.6 & 12.2 & 13.2 & & & & 15.7 & 3568 & 2078 \\
\hline & $13-14$ & 60.6 & 64.5 & 13.6 & 11.9 & 0.8 & 0.72 & 15.7 & 16.5 & 4771 & 305 \\
\hline \multirow{3}{*}{$\begin{array}{r}\text { Trifoliate } \\
\text { orange }\end{array}$} & $5-6$ & 58.5 & 58.3 & 11.8 & 12.2 & 0.99 & 0.73 & 12.0 & 17.2 & 1693 & 107 \\
\hline & $9-1$ & & 60.1 & 12.9 & 13.7 & & 0.87 & 13.8 & 15.8 & 3891 & 293 \\
\hline & $13-1$ & & & & 12.1 & & 0.73 & 15.5 & 16.9 & 4589 & 374 \\
\hline \multirow{3}{*}{$\begin{array}{l}\text { Volkamer } \\
\text { lemon }\end{array}$} & $5-6$ & 55.7 & 51.0 & 10.1 & 10.8 & 0.86 & 0.65 & 11.9 & 17.7 & 2472 & 190 \\
\hline & $9-10$ & & & 10.7 & 12.0 & & 0.75 & 12.4 & 16.0 & 4900 & 4628 \\
\hline & $13-14$ & 57.5 & 61.4 & 11.6 & 11.1 & 0.85 & 0.72 & 13.8 & 15.5 & 7187 & 624 \\
\hline \multirow[t]{3}{*}{ Cuttings } & $5-6$ & & 63.5 & & 12.4 & & 0.89 & & 14.0 & & 85 \\
\hline & $9-10$ & & 62.0 & & 12.8 & & 0.83 & & 15.5 & & 263 \\
\hline & $13-14$ & & 63.0 & & 11.6 & & 0.75 & & 15.7 & & 312 \\
\hline Mean & $5-6$ & 57.0 & 56.4 & 10.7 & 11.5 & 0.92 & 0.71 & 11.7 & 17.1 & 1642 & 1362 \\
\hline & $9-10$ & 59.0 & 60.8 & 11.5 & 12.7 & 0.90 & 0.83 & 12.8 & 15.4 & 4375 & 3465 \\
\hline & $13-14$ & 59.7 & 63.3 & 12.7 & 11.6 & 0.90 & 0.73 & 14.3 & 16.0 & 6217 & 4618 \\
\hline Least significant & 6 & 1.8 & 1.2 & 0.3 & 0.5 & 0.04 & 0.04 & 0.4 & 0.6 & 403 & 594 \\
\hline & 9 & 1.4 & NS & 0.4 & 0.7 & & 0.0 & 0.9 & 0.9 & 666 & 753 \\
\hline & 14 & 1.7 & 2.4 & 0.7 & 0.7 & 0.10 & 0.04 & 1.1 & 1.0 & 2073 & 1036 \\
\hline
\end{tabular}

${ }^{\mathrm{z}}$ Data are means of a 2-year period, e.g., Years 5 and 6.

${ }^{\mathrm{y}}$ Calculated by multiplying the yield from Table 2 for the given year $\times \%$ juice $\times \%$ soluble solids $\times$ no. tree/ha. NS $=$ nonsignificant.

trees on Volkamer lemon were precocious in bearing and relatively high-yielding thereafter; but, the 'Valencia' trees on that rootstock produced low juice-quality fruit and had high losses to blight. That combination of attributes presented in a rootstock selection guide (Castle et al., 2006) might discourage use of Volkamer lemon; however, the financial analysis showed that at both locations, although $\approx 50 \%$ of the trees were replaced after 15 years, the trees on that rootstock had one of the highest cash flows and internal rates of within a citrus rootstock. If those deficiencies are reduced or absent, the evidence from our trials suggested that even a moderately productive rootstock combined with tolerance to blight, high juice quality, and the proper matching of tree vigor with planting density would outperform trees on a rootstock like Volkamer lemon. That point is illustrated by comparing the "blight with resets" results of the 'Valencia' trees on Carrizo citrange with those on Volkamer lemon at each location and between the two locations (Table 6). Blight loss was $\approx 50 \%$ less for the trees on Carrizo citrange than on Volkamer lemon regardless of location; juice quality was similar for each rootstock at each location so those factors are not considered in the comparison. At Indiantown, the 32\% higher cumulative yield/tree of the trees on Volkamer lemon (Table 2) was sufficient to offset their lower juice quality and greater blight losses resulting in a larger cash flow than for the trees on Carrizo citrange. At Avon Park, the difference in cumulative yield/tree between the two rootstocks was only $12 \%$ and there were $42 \%$ more trees than at Indiantown. Thus, the increased planting density at Avon Park coupled with similar yields/tree between the two rootstocks (Table 2) led to a cash flow result for the trees on Carrizo citrange that was the best overall financial performance between both locations. The effect of planting density explains the generally higher cash flows and IRRs for the trees at Avon Park versus Indiantown, but the relative financial outcomes remained largely unchanged among rootstocks. Higher planting density has the potential to improve grower returns and function as a buffer to a certain extent against changes in economic factors such as fruit or juice prices (Robinson et al., 2007).

Planting density had a positive influence on rootstock financial outcomes when comparisons were made between locations for a particular rootstock. Another aspect of tree spacing is whether trees on certain rootstocks with lower vigor and smaller tree size were better suited for higher density and on that basis, outperformed those less suited for the 358 trees/ha planting density at Avon Park. The trees on trifoliate orange are the best example because of all rootstocks, those trees were the smallest and produced good yields of fruit with excellent juice quality. Nevertheless, their performance was still far below the yields (Table 2) and soluble solids production (Table 4) of the trees on Volkamer lemon. Even if the spacing at Avon Park for the trees on trifoliate orange was adjusted to 538 trees/ha, total yield would have been 7\% below that of the trees on Volkamer lemon at the original density of 358 trees/ha. That comparison supports the contention that when selecting rootstocks for a citrus grove of juice oranges and properly matching planting density with tree size and site factors, yield can dominate performance.

The effect of spacing was obvious with the trees on Swingle citrumelo. At a planting density of 252 trees/ha in Indiantown, they 
Table 5. Rootstock effects on pasteurized 'Valencia' orange juice flavor and quality.

\begin{tabular}{|c|c|c|c|c|c|c|c|c|}
\hline \multirow[b]{2}{*}{ Rootstock } & \multicolumn{4}{|c|}{ 1991-1992 season } & \multicolumn{4}{|c|}{ 1992-1993 season } \\
\hline & $\mathrm{SSC}^{\mathrm{y}}$ & Acid $^{y}$ & Ratio $^{y}$ & Flavor $^{x}$ & $\mathrm{SSC}$ & Acid & Ratio & Flavor \\
\hline Carrizo citrange & 11.8 & 0.83 & 14.2 & 7.2 & 12.3 & 0.87 & 14.1 & 7.3 \\
\hline Cleopatra mandarin & 11.8 & 0.82 & 14.3 & 7.2 & 12.1 & 0.75 & 16.1 & 7.1 \\
\hline Rough lemon & 10.7 & 0.78 & 13.7 & 6.9 & 10.5 & 0.71 & 14.9 & 7.4 \\
\hline Sour orange & 12.7 & 0.88 & 14.4 & 7.4 & 12.3 & 0.78 & 15.7 & 6.7 \\
\hline Swingle citrumelo & 11.5 & 0.81 & 14.1 & 7.0 & 12.6 & 0.79 & 15.3 & 7.3 \\
\hline
\end{tabular}

${ }^{\mathrm{z}}$ Data are for one 400-kg sample/rootstock normalized for ratio and harvested at Indiantown from four replicates when the trees were 16 and 17 years old.

${ }^{y} \mathrm{SSC}$ is soluble solids concentration; Acid is \% acid; Ratio is SCC/acid.

${ }^{\mathrm{x}}$ Flavor judged by an experienced taste panel using an Hedonic scale: $1=$ dislike extremely; $5=$ neither like nor dislike; 9 = like extremely. There were no significant differences among rootstocks in either season.

had a positive cash flow only under the "no blight" scenario; when adjusted to 358 trees/ ha, the cash flow improved to a relatively low, but positive value that exceeded the Cleopatra mandarin cash flow. Trees on other rootstocks like sour orange or sweet orange had relatively good cash flows, but not the highest ones although the trees on sweet orange and sour orange produced good to excellent quality fruit, respectively, and virtually none were lost to blight. It was slowness to bearing (Table 2) that resulted in the lower cash flow of the trees on sour orange at Indiantown, but essentially the same bearing behavior at Avon Park at the higher planting density resulted in an excellent cash flow. 'Valencia' trees on Cleopatra mandarin in Florida are vigorous and well-known to be slow-bearing (Castle, 1987; Wutscher, 1979) as occurred at both locations. Those attributes resulted in the lowest cash flow at Indiantown (except for Swingle citrumelo) where substantial cropping only began when the trees were $\approx 10$ years old, the same age at which substantial blight losses also began to occur.

Robustness of financial interpretation. If financial interpretation is a useful tool, how broadly can it be applied and when in the life of a field trial are the basic conclusions about rootstocks determined? Horticulturally, our rootstock results were classic for Florida and are very representative in general for 'Valencia', likewise for rootstock responses to blight (Castle and Baldwin, 1995; Castle and Phillips, 1980; Castle et al., 1993; Wutscher and Bowman, 1999). Rootstock effects on yield and juice quality were apparent within the first few cropping years; by the time the trees had cropped four to six times and additional juice quality data were gathered, the differences among rootstocks were well established and changed little thereafter. After 6 cropping years, the trees were $\approx 10$ years old and the same relative financial differences were apparent then as at the end of the trial. The trees on many of the trial rootstocks at that time had produced $40 \%$ to $50 \%$ of their total yield. If using horticultural plus financial interpretation is validated in further studies, the impact on the time of the plant improvement process of creation to release would be meaningfully reduced.

Biological factors that could influence our financial outcomes are rootstock traits, inherent fruit quality of the scion, and site conditions that could change rootstock performance or the relationship among rootstocks under evaluation; economic factors include whether the fruit is being grown for the fresh or juice market, tree losses and replacement costs, and planting density. Our results showed that financial analysis has value when there are rootstock differences. Rootstocks with similar or offsetting traits resulting in similar horticultural outcomes were not distinguished by financial analysis. Nevertheless, financial analysis would distinguish among rootstocks, e.g., with similar long-term productivity, but different cropping patterns. Trees on a rootstock that was precocious would likely be more profitable than on a rootstock less quick to bear under otherwise similar circumstances.

The role of the scion variety in rootstock evaluation and financial interpretation poses an interesting question, i.e., will the results vary if the scion is a high- or low-quality orange? A high-quality juice orange like 'Valencia' might not be very much affected by citrus rootstocks or it might be ideally suited because it would allow the fullest expression of rootstock effects. The 'Valencia' trees in our trials responded to the rootstocks that exhibited a range of attributes and effects on tree vigor, juice quality, yield, and blight tolerance resulting in useful financial separations. The same question can be applied to a low-quality juice orange like 'Hamlin', i.e., are rootstock differences relatively diminished or magnified? The evidence from our 'Valencia' trials and another unpublished 13-year 'Hamlin' trial with some of the same rootstocks indicates that rootstocks sufficiently affect all aspects of horticultural performance regardless of scion and that financial interpretations are possible and worthwhile. However, it remains to be demonstrated if this approach can be applied to field research with fresh fruit cultivars. Also, in an apple study, financial analysis showed that the planting systems had differential sensitivity to fruit price (Robinson et al., 2007), something we did not determine in our study.

We found that financial outcomes were not exceptionally sensitive to tree losses that occurred before the trees began to crop. The initial tree losses from Phytophthora infections had little impact on the cash flows after 15 years. Afterward, as trees age, their annual yields increase and represent an increasingly larger proportion of their total productivity over a given period. Thus, a tree lost at age 12 years could have more impact on grove performance than one lost at age 4 years, but that impact is also a function of planting density. The impact is diminished as planting density increases as clearly seen with the trees on Cleopatra mandarin at Avon Park versus Indiantown under the "blight with resets" scenario (Table 6).

Rootstock effects on inherent scion fruit quality. Ancillary to the issue of scionrootstock interactions and their effects on financial outcomes is the question of whether a rootstock can improve fruit soluble solids, the basis for sale of fruit to processors in Florida. The answer appears to be no because at Indiantown, the soluble solids concentration of the fruit from the 'Valencia' cuttings was higher than in the fruit from virtually all of the budded trees with only a few exceptions. Those exceptions probably resulted from differences in mean fruit size with smaller fruit having higher soluble solids concentrations like produced by the trees on trifoliate orange at both locations (Barry et al., 2004). Thus, it can be concluded again that yield is perhaps the key element in profitability.

Soil variability and rootstock performance. The soils at the two locations are representative of the major citrus-growing areas of Florida. Horticultural variability among replicates was relatively low among rootstocks at Avon Park, $\approx 10 \%$ to $20 \%$ difference between high- and low-yielding replicates (data not given) as compared with that at Indiantown where the site/soil was highly variable. We showed, e.g., that trees on one rootstock, Swingle citrumelo were limited in their performance at the Indiantown location for two reasons: they were spaced too far apart and the soil at certain sites was not well suited primarily because of its calcareous nature. By adjusting their spacing in the hypothetical analysis, their performance was improved and even more so when a financial interpretation was applied to only the data from the higher-performing replicates growing in more favorable soil (Table 6; Fig. 3).

\section{Conclusions}

We conclude that a new model involving horticultural and financial evaluation should be used in citrus rootstock trials. The model is sufficiently flexible to accommodate a range of trial variables, including scion cultivar, tree spacing, and soil and site factors. Financial analysis integrates horticultural (including harvesting), pest, and disease rootstock data to provide a more complete understanding of all factors involved in interpreting rootstock performance. The model has certain limitations: 1) at present, the application of the model to fresh fruit cultivars has not been demonstrated; 2) a minimum time is required to collect an appropriate data set for the model to be valid; thus, it would not be useful in preliminary screening-type field trials with the objective to identify the most promising rootstocks; and 3) although the model is appropriate for a number of research situations, 


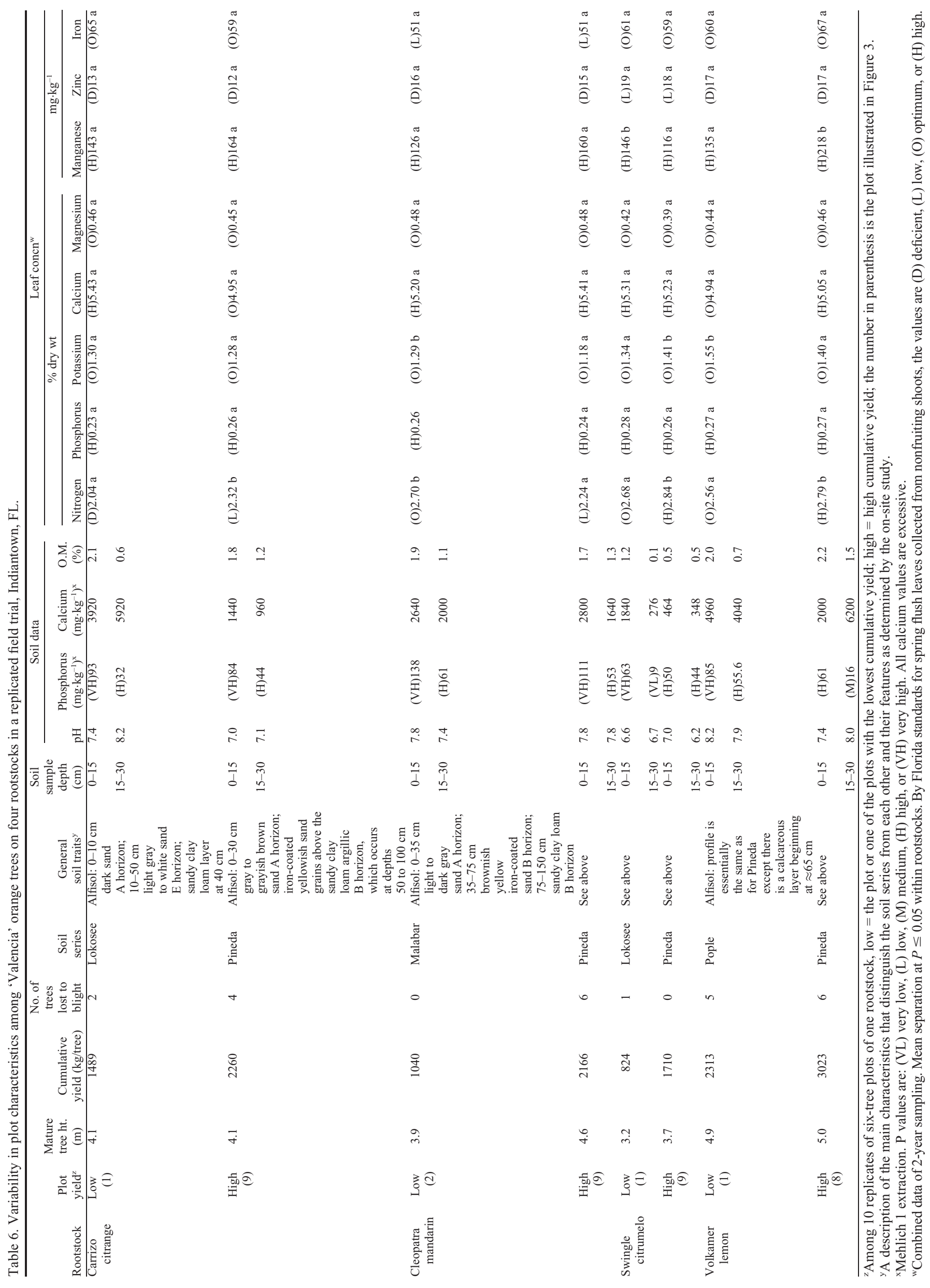

HortScience Vol. 45(4) April 2010 

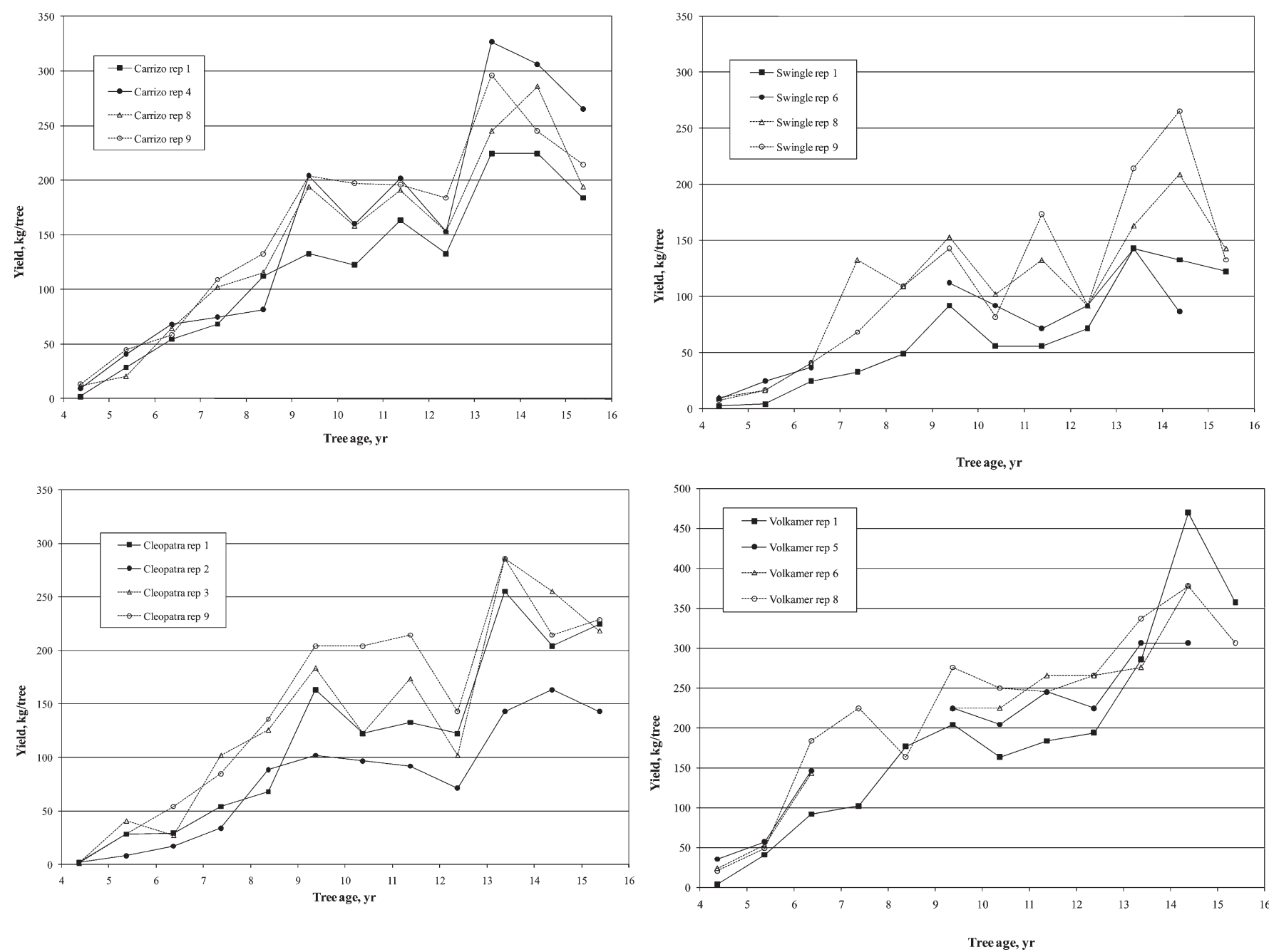

Fig. 3. Productivity among the highest- and lowest-yielding replicates of 'Valencia' orange on four of 12 rootstocks in a field trial planted at 252 trees/ha at Indiantown, FL.

Table 7. Discounted annual cash flows (US dollars/ha) and internal rates of return (IRR) based on 15-year (1980-1995) historical data for a hypothetical 1-ha grove of 'Valencia' trees on selected rootstocks planted at Indiantown (252 trees/ha) or Avon Park (358 trees/ha), FL."

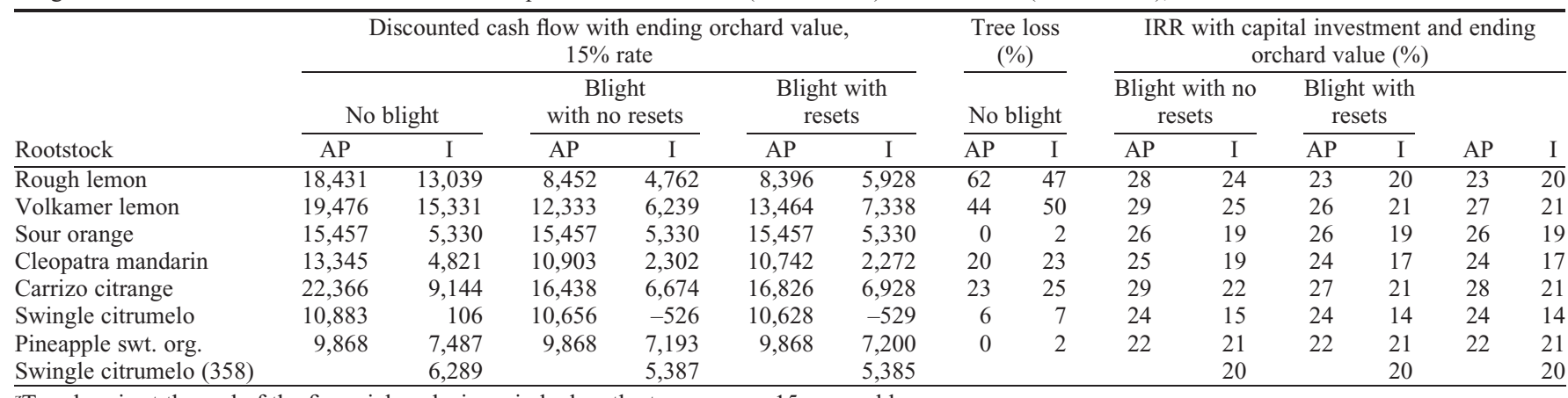

${ }^{\mathrm{z}}$ Tree loss is at the end of the financial analysis period when the trees were $\approx 15$ years old.

financial outcomes may be deemed relatively unimportant by citrus growers when choosing rootstocks based on perceived risk. Those risks associated with individual horticultural traits can result in different decisions than those supported by financial interpretations. Swingle citrumelo is the principal commercial rootstock in Florida, not Volkamer lemon (Florida Citrus Budwood Program, 2008). The results of our study would suggest the opposite choice, but trees on Swingle citrumelo are reasonably productive, yield fruit with very good juice quality and size, and have excellent survival history. The sum of those traits explains its popularity and success. Furthermore, our results support the general recognition of the excellent horticultural attributes of trees on Carrizo citrange as now amended with financial analysis.

\section{Literature Cited}

Barry, G.H., W.S. Castle, and F.S. Davies. 2004. Soluble solids accumulation in 'Valencia' sweet orange as related to rootstock selection and fruit size J Amer. Soc. Hort Sci. 129.594 598.

Bauer, M., W.S. Castle, B.J. Boman, and T.A. Obreza. 2005. Economic longevity if citrus trees on Swingle citrumelo rootstock and their suitability for soils of the Indian River region. Proc. Fla. State Hort. Soc. 118:24-27.

Bauer, M., W.S. Castle, B.J. Boman, and T.A. Obreza. 2007. Field guide to soil identification for Florida's citrus-growing regions. Univ. Fla. Coop. Extension Publ. SP-362.

Bevington, K.B. and B.R. Cullis. 1990. Evaluation of rootstocks for Marsh and Davis grapefruit in 
the Murray Region of New South Wales. Aust. J. Exp. Agr. 30:405-411.

Bierman, H. and S. Smidt. 2006. The capital budgeting decision, ninth edition. Economic analysis of investment projects. Routledge Publ., Florence, KY.

Boswell, S.B., D.R. Atkin, C.D. McCarty, and R.D. Copleland. 1978. A preliminary assessment of citrus spacing on production using a 'substandard' rootstock-scion combination. HortScience 13:468-469.

Boswell, S.B., C.D. McCarty, K.W. Hench, and L.N. Lewis. 1975. Effect of tree density on the first ten years of growth and production of 'Washington' navel orange trees. J. Amer. Soc. Hort. Sci. 100:370-373.

Breedt, H.J., I.J. Froneman, and C.F. Human. 1996. Strategies for breeding and evaluation of citrus rootstocks and cultivars in South Africa. Proc. Int. Soc. Citricult. 1:150-153.

Castle, B., M. Bauer, B. Bowman, T. Obreza, and E. Stover. 2004. Matching soils with rootstocks, especially Swingle citrumelo. Citrus Ind. 85:15-18.

Castle, W.S. 1983. Growth, yield, and cold hardiness of 7-year-old 'Bearss' lemon trees on 27 rootstocks. Proc. Fla. State Hort. Soc. 96:23-25.

Castle, W.S. 1987. Citrus rootstocks, p. 361-399. In: Rom, R.C. and R.F. Carlson (eds.). Rootstocks for fruit crops. Wiley, Hoboken, NJ.

Castle, W.S. 1995. Rootstocks as a fruit quality factor in citrus and deciduous tree crops. N. Z. J. Crop Hortic. Sci. 23:383-394.

Castle, W.S. and J.C. Baldwin. 1995. Tree survival in long-term citrus rootstock field trials. Proc. Fla. State Hort. Soc. 108:73-77.

Castle, W.S. and J.C. Baldwin. 2005. Rootstock effects on 'Hamlin' and 'Valencia' orange trees growing at Central Ridge and flatwoods locations. Proc. Fla. State Hort. Soc. 118:4-14.

Castle, W.S. and F.G. Gmitter, Jr. 1998. Rootstock and scion selection, p. 21-34. In: Timmer, L.W. and L.W. Duncan (eds.). Citrus health management. APS Press, St. Paul, MN.

Castle, W.S. and R.L. Phillips. 1977. Potentially dwarfing rootstocks for Florida citrus. Proc. Intl. Soc. Citricult. 2:558-561.

Castle, W.S. and R.L. Phillips. 1980. Performance of 'Marsh' grapefruit and 'Valencia' orange trees on eighteen rootstocks in a closely spaced planting. J. Amer. Soc. Hort. Sci. 105:496-499.

Castle, W.S., J.C. Baldwin, and J.W. Grosser. 2000. Performance of 'Washington' navel orange trees in rootstock trials located in Lake and St. Lucie counties. Proc. Fla. State Hort. Soc. 113:106-111.

Castle, W.S., J. Nunnallee, and J.A. Manthey. 2009. Screening citrus rootstocks and related selections in soil and solution culture for tolerance to low-iron stress. HortScience 4 : 638-645.

Castle, W.S., K.D. Bowman, J.H. Graham, Jr., and D.P.H. Tucker. 2006. Florida citrus rootstock selection guide. Univ. Fla. Coop. Extension Publ. SP-248.

Castle, W.S., D.P.H. Tucker, A.H. Krezdorn, and C.O. Youtsey. 1993. Rootstocks for Florida. 2nd Ed. Univ. Fla. Coop. Ext. Publ. SP-42.

Derrick, K.S. and L.W. Timmer. 2000. Citrus blight and other diseases of recalcitrant etiology. Annu. Rev. Phytopathol. 38:181-205.

Economides, C.V. 1993. Growth, yield, and fruit quality of nucellar Frost 'Marsh' grapefruit on fifteen rootstocks in Cyprus. J. Amer. Soc. Hort. Sci. 118:326-329.

Fellers, P.F. 1990. Florida's juice standards for grades and their differences from United States standards for grades and United States Food and Drug Administration standards of identity. Proc. Fla. State Hort. Soc. 103:260-265.

Ferguson, L., N. Sakovich, and M. Roose. 1990. California citrus rootstocks. Univ. Calif. Ext. Publ. 21477.

Florida Agricultural Statistics Service. 2009. Citrus summary 2007-08. USDA, NASS, Orlando, FL.

Florida Citrus Budwood Program. 2008. Annual report. Bureau of Citrus Budwood Registration, Div. Plant Ind., Fla. Dept. Agr. Consum. Serv.

Foguet, J.L. 2000. New rootstocks for the citrus industry in Argentina. Proc. Int. Soc. Citricult. $1: 56-57$.

Gmitter, F.G., Jr, C. Chen, M.N. Rao, and J.R. Soneji. 2007. Citrus fruits, p. 265-279. In: Kole, K.R. (ed.). Fruits and nuts, genome mapping, and molecular breeding in plants. Vol. 4. Springer, Heidelberg, Germany.

Hutchison, D.J., C.J. Hearn, and F.W. Bistline. 1992. The performance of 'Valencia' orange trees on 21 rootstocks in Florida flatwoods. Proc. Fla. State Hort. Soc. 105:60-63.

Kramer, A. 1960. A rapid method for determining significance of differences from rank sums. Food Technol. 14:576.

Lee, R.F., L.J. Marais, L.W. Timmer, and J.H. Graham. 1984. Syringe injection of water into the trunk: A rapid diagnostic test for citrus blight. Plant Dis. 68:511-513.

Ling, P., L.W. Duncan, Z. Deng, D. Dunn, X. Hu, S. Huang, and F.G. Gmitter, Jr. 2000. Inheritance of citrus nematode resistance and its linkage with molecular markers. Theor. Appl. Genet. 100:1010-1017.

Mann, K.K., A.W. Schumann, and T.A. Obreza. 2009. Assessment of soil variability and its impact on citrus production: A statistical approach. Proc. Fla. State Hort. Soc. 122:51-59.

Muraro, R.P. and W.S. Castle. 1996. Resetting and replanting options in Florida citrus groves and the financial consequences. Proc. Fla. State Hort. Soc. 109:128-131.

Muraro, R.P., W.S. Castle, T.A. Wheaton, J.D. Whitney, and D.P.H. Tucker. 1995. An analysis of how planting density and rootstock vigor affect the economic performance of 'Valencia' trees. Proc. Fla. State Hort. Soc. 108:160-164.
Newcomb, D.A. 1978. Selection of rootstocks for salinity and disease resistance. Proc. Int. Soc. Citricult. 1:117-120.

Obreza, T.A. and K.T. Morgan (eds.). 2008. Nutrition of Florida citrus trees. 2nd Ed. Univ. Fla. Coop. Ext. Publ. SL-253.

Phillips, R.L. and W.S. Castle. 1977. Evaluation of twelve rootstocks for dwarfing citrus. J. Amer. Soc. Hort. Sci. 102:526-528.

Robinson, T.L., A.N. Lakso, and S.G. Carpenter. 1991. Canopy development, yield, and fruit quality of 'Empire' and 'Delicious' apples trees grown in four orchard production systems for 10 years. J. Amer. Soc. Hort. Sci. 116:179-187.

Robinson, T.L. and S.A. Hoying. 2004. Which high-density orchard planting system for replant sites in New York is most productive and profitable? Acta Hort. 636:701-709.

Robinson, T.L., A.M. DeMaree, and S.A. Hoying. 2007. An economic comparison of five high density apple planting systems. Acta Hort. 732: 481-489.

Roose, M.L., D.A. Cole, D. Atkin, and R.S. Kupper. 1989. Yield and tree size of four citrus cultivars on 21 rootstocks in California. J. Amer. Soc. Hort. Sci. 114:678-684.

Rouse, R.E. 2000. Citrus fruit quality and yield of six Valencia clones on 16 rootstocks in the Immokalee Foundation Grove. Proc. Fla. State Hort. Soc. 113:112-114.

Stover, E. and W.S. Castle. 2002. Citrus rootstock usage, characteristics, and selection in the Florida Indian River region. HortTechnology 12:143-147.

Wheaton, T.A., W.S. Castle, J.D. Whitney, and D.P.H. Tucker. 1991. Performance of citrus scion cultivars and rootstocks in a high density planting. HortScience 26:837-840.

Wheaton, T.A., J.D. Whitney, W.S. Castle, R.P. Muraro, H.W. Browning, and D.P.H. Tucker. 1995a. Citrus scion and rootstock, topping height, and tree spacing affect tree size, yield, fruit quality, and economic return. J. Amer. Soc. Hort. Sci. 120:861-870.

Wheaton, T.A., J.D. Whitney, W.S. Castle, R.P. Muraro, H.W. Browning, and D.P.H. Tucker. 1995b. Tree vigor important in citrus tree spacing and topping. Proc. Fla. State Hort. Soc. 108:63-69.

Wutscher, H.K. 1979. Citrus rootstocks. Hort. Rev. (Amer. Soc. Hort. Sci.) 1:237-269.

Wutscher, H.K. and F.W. Bistline. 1988. Performance of 'Hamlin' orange on 30 citrus rootstocks in southern Florida. J. Amer. Soc. Hort. Sci. 113:493-497.

Wutscher, H.K. and K.D. Bowman. 1999. Performance of 'Valencia' orange on 21 rootstocks in central Florida. HortScience 33:622-624.

Wutscher, H.K. and L.L. Hill. 1995. Performance of 'Hamlin' orange on 16 rootstocks in eastcentral Florida. HortScience 30:41-43.

Ziegler, L.W. 1966. Economic aspects of citrus stocks and scions. Citrus Industry 47:18-19. 